\title{
ENERGY PRODUCTION IN GLUCONOBACTER LIQUEFACIENS
}

\author{
A. H. STOUTHAMER \\ Laborator tor Microbiology, State University, Utrecht (The Netherlands) \\ (Rerived May I2th, I96I)
}

\section{SUMMARY}

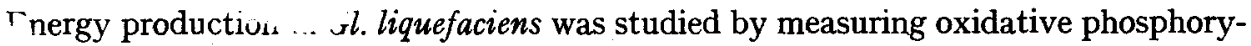
. wion in cell-free extracts and molar growth yield in growing cultures.

$\mathrm{P} / \mathrm{C}$ ratios were found very low and ranged from 0.09 for $\mathrm{DPNH}$ to 0.40 for glucose 6-phosphate, that is about $5 \%$ of the efficiency in animal mitochondria.

The low $\mathrm{P} / \mathrm{O}$ ratios truly represent the low efficiency of energy transfer in this organism, as in growirg cultures the molar growth yield is equally low.

From the $\mathrm{P} / \mathrm{O}$ and the molar growth yield for the oxidation from ethanol to acetate the yield in milligram dry cells/mole of ATP produced was calculated at ro $\mathrm{mg} / \mathrm{mmole}$ ATP. This value is in close agreement with that reported for other microorganisms.

The low efficiency of energy transfer is partly explained by the presence of only one cytochrome in this organism. The absence of respiratory control (indicated by insensitivity to DNP) suggests that the oxidation is very loosely coupled to phosphorylation.

\section{INTRODUCTION}

In previous studies ${ }^{1-3}$ it was shown that the main oxidative pathways in Gluconobacter liquefaciens are the pentosephosphate cycle and the citric acid cycle. No glycolytic pathway and no Entner-Doudoroff system are present. However, a number of substrates pass through one or more unphosphorylated oxidations before entering the pentosephosphate cycle. Glucose, f.i., is rapidly oxidized by particulate enzymes in the cell membrane to 2,5 -diketogluconate, which is slowly metabolized by the pentosephosphate cycle after initial reduction to gluconic acid and phosphorylation of the latter.

Cells grown on galactose oxidize glucose with much higher $\mathrm{O}_{2}$ uptakes and $\mathrm{CO}_{2}$ evolutions than glucose-grown cells. This is due to the absence of the 2-ketogluconooxydase and the weak activity of the gluconooxidase in the cell membranes of galactose-grown cells. These cells consequently oxidize glucose rapidly to gluconate which is only partly oxidized to 2 -ketogluconate but for the greater part enters the cell where it is phosphorylated and broken down by the soluble enzymes of the pentosephosphate cycle.

Abbreviations: G6P, glucose-6-phosphate; M6P, mannose-6-phosphate; TCA, trichloroacetic acid; 6-PG, 6-phosphogluconate. 
Galactose is oxidized by adapted cells of Gl. liquefaciens in the same way as in Pseudomonas saccharophila 4 that is by oxidation via galactonate to 2 -keto-3-deoxygalactonate, subsequent phosphorylation and aldolytic breakdown to pyruvate and triosephosphate.

These peculiar pathways of carbohydrate breakdown made us wonder how much energy this organism obtains from some of its characteristic (unphosphorylated) oxidations (glucose to gluconate, ethanol to acetate, glycerol to dihydroxyacetone). Oxidative phosphorylation and the yield of cell material per mole of carbon source was therefore studied with a variety of substrates.

\section{METHODS}

Mass cultures were grown on glucose-chalk medium as described previously ${ }^{5}$. Galactose-grown cells were obtained from a liquid medium containing: peptone, $0.5 \%$; yeast extract, $0.5 \% ; \mathrm{KH}_{2} \mathrm{PO}_{4}, 0 . \mathrm{I} \%$ and galactose, 0.4 or $2 \% . \mathrm{pH} 5.8$. The synthetic medium contained: $\mathrm{KH}_{2} \mathrm{PO}_{4}, 0.3 \% ; \mathrm{Na}_{2} \mathrm{HPO}_{4}, 0.2 \% ; \mathrm{NaCl}, 0 . \mathrm{I} \% ;\left(\mathrm{NH}_{4}\right)_{2} \mathrm{SO}_{4}$, $0.5 \% ; \mathrm{MgSO}_{4} \cdot 7 \mathrm{H}_{2} \mathrm{O}, 0 . \mathrm{I} \% ; \mathrm{FeSO}_{4} \cdot 6 \mathrm{H}_{2} \mathrm{O}$, o.or $\%$ and a carbon source, $0.5 \%$. This medium was prepared by dissolving the salts in boiling tap water. After filtration the medium was sterilized at $I I 6^{\circ}$ for $I 5 \mathrm{~min}$. The carbon source was added aseptically as a concentrated solution, sterilized separately at $\mathrm{I} 6^{\circ}$ for Io min. $\mathrm{pH} 5.8$. The liquid media were dispensed in shallow layers in erlenmeyer flasks (200 $\mathrm{ml}$ in a $\mathrm{I}-1$ flask). After inoculation they were incubated at $30^{\circ}$ in a shaking machine. The cells from these media were harvested and washed as described before ${ }^{5}$.

The dry weight of the cells was determined by drying the thoroughly washed cells at $105^{\circ}$ to constant weight. By measuring the absorbancy at $600 \mathrm{~m} \mu$ of a range of dilutions of a culture of known dry weight a standard curve relating absorbancy to dry weight was obtained.

Cell-free extracts were prepared by sonic desintegration for to min in a Mullard Sonic Desintegrator as described before ${ }^{3}$. The suspension was then centrifuged for $30 \mathrm{~min}$ at $\mathrm{I} 2000 \times \mathrm{g}$ in an MSE superspeed centrifuge at $4^{\circ}$ to eliminate cell debris. Suspensions of particles were obtained by centrifugation at $75000 \times g$ as described before ${ }^{3}$.

Oxidations by resting cells and cell-free extracts were measured by conventional Warburg techniques.

\section{Oxidative phosphorylation}

As glucose and G6P are rapidly oxidized by cell-free extracts of Gl. liquefaciens, glucose could not be used as a phosphate acceptor. Mannose seemed a suitable acceptor as it is only very slowly oxidized (to mannonate), whereas M6P is not oxidized at all. Indeed the $\mathrm{O}_{2}$ consumption of cell-free extracts with mannose, ATP and hexokinase was equal to the endogenous $\mathrm{O}_{2}$ uptake. The suitability of mannose as a phosphate acceptor would be impaired by the presence of a M6P-phosphatase, which would cause $\mathrm{P} / \mathrm{O}$ ratios to be too low. It was found, however, that no inorganic phosphate was split off from M6P (prepared from mannose and less than an equimolar amount of ATP and hexokinase) under the conditions of the manometric experiments. A phosphatase for $\mathrm{M} 6 \mathrm{P}$ is thus absent.

Oxidative phosphorylation was consequently measured with mannose as acceptor 
in the following system: sodiumacetate-acetic acid buffer, $200 \mu$ moles; mannose, I5 $\mu$ moles; $\mathrm{MgCl}_{2}$, $\mathrm{I}_{5} \mu$ moles; ATP, $2.5 \mu$ moles; DPN and TPN $0.3 \mu$ mole (when indicated); hexokinase $500 \mu \mathrm{g}$ (Sigma, type III) and $0.4 \mathrm{ml}$ crude cell-free extract (containing Io-I3 $\mathrm{mg}$ protein). The total volume in the main compartment of the Warburg vessel was $1.7 . \mathrm{ml}, \mathrm{pH}$ 6.0. The sidebulb contained ro $\mu$ moles substrate in $0.2 \mathrm{ml}$. In the centre well o. I ml Io \% $\mathrm{KOH}$. The $\mathrm{O}_{2}$ uptake was measured for $30 \mathrm{~min}$. Phosphorylation was measured by the disappearance of inorganic phosphate. One millilitre of the content of the main compartment of the Warburg vessel was added to $0.5 \mathrm{ml} 0.8 \mathrm{M}$ TCA. Protein was sedimented by centrifugation and in a $0.5-\mathrm{ml}$ sample of the supernatant inorganic phosphate was determined by the method of FISKE AND SUBBAROW ${ }^{6}$.

An ATPase activity of the cell-free extracts might remove ATP and influence the $\mathrm{P} / \mathrm{O}$ ratios. ATPase activity was determined in a system with acetate buffer $\mathrm{pH} 6.0$, $200 \mu$ moles; $\mathrm{MgCl}_{2}$, I5 $\mu$ moles; ATP, $\mathrm{I}_{5} \mu$ moles and $0.4 \mathrm{ml}$ cell-free extract in a total volume of $1.9 \mathrm{ml}$. The mixture was incubated for $30 \mathrm{~min}$ and the released inorganic phosphate was determined as described. The amount of inorganic phosphate liberated from ATP was I. $4 \mu$ moles/mg protein/h for the crude cell-free extract as well as for the particle free supernatant, and $2 \mu$ moles $/ \mathrm{mg}$ protein $/ \mathrm{h}$ for the particles. Though ATPase is more active in the particulate fraction most of the ATP is hydrolyzed by the soluble enzyme as the particulate fraction contains only $25 \%$ of the protein in the total extract. During the $30 \mathrm{~min}$ of an experiment on oxidative phosphorylation (with $\sim$ Io mg of protein) the ATPase would remove $7.8 \mu$ moles of ATP.

This ATPase activity of the extracts will reduce the observed $P / O$ ratios unless it can be shown that the hexokinase consumes ATP at a much higher rate.

Hexokinase activity was measured in a system containing: acetate buffer $\mathrm{pH}$ 6.o, I50 $\mu$ moles; $\mathrm{MgCl}_{2}$, I5 $\mu$ moles; ATP, I5 $\mu$ moles; mannose, I5 $\mu$ moles and hexokinase, $500 \mu \mathrm{g}$ in a total volume of $2.0 \mathrm{ml}$. After 5 , Io and I5 min incubation at $30^{\circ}$ a sample of $0.3 \mathrm{ml}$ was taken from this mixture. To this sample $0.3 \mathrm{ml} 5 \% \mathrm{ZnSO}_{4}$ and $0.3 \mathrm{ml} 0.3 \mathrm{~N} \mathrm{Ba}(\mathrm{OH})_{2}$ were added to precipitate proteins and inorganic phosphate, ATP, ADP and M6P as their Ba-salts. After centrifugation the remaining mannose was determined in a $0.3-\mathrm{ml}$ sample of the supernatant by the CyR I of DischE, SheTtLES AND OsNos7. With this system it was shown that $12 \mu$ moles of mannose could be phosphorylated in $5 \mathrm{~min}$. At this high rate at least $72 \mu$ moles of mannose could be phosphorylated by hexokinase during an experiment on oxidative phosphorylation. As the rate of the ATPase was so much lower it was argued that the ATPase activity would not interfere with oxidative phosphorylation. This was proved by showing that the addition of $0.4 \mathrm{ml}$ of cell-free extract to the hexokinase test system did not reduce the amount of mannose that was phosphorylated.

\section{Cytochromes}

To detect the absorption maxima of the cytochromes in whole cells, the spectrum of suspensions of bacteria were measured against a blank of diluted milk in a Beckman spectrophotometer. The absorption of the milk suspension (mainly due to light scattering) was only slightly influenced by the wavelength (at $400 \mathrm{~m} \mu$ the absorption was only $20 \%$ greater than at $600 \mathrm{~m} \mu$ ). Because of this the measured spectrum does not represent the true cytochrome spectrum in the cells, but it gives a very good indication of the wavelengths at which the cytochromes show their absorption maxima 
and it has the advantage that very thick suspensions can be examined. The difference spectrum of particles was measured with particles suspended in $0.007 M$ DL-lactate (reduced state) against particles shaken in air for $\mathrm{I} h$ (oxidized state). Protein was measured by a biuret method ${ }^{\mathbf{1 0}}$. Galactose was measured with the anthrone reagent according to the method of Trevelyan AND Harrison ${ }^{9}$. Fructose was measured by the method of $\operatorname{RoE}^{10}$ and galactonate by that of Hestrin ${ }^{11}$.

\section{RESULTS}

$\mathrm{QO}_{2}$ for the oxidation of some substrates by cell-free extracts of galactose-grown cells

The $Q_{\mathrm{O}_{2}}$ values for the oxidation of several substrates by cell-free extracts of galactose-grown cells are given in Table I. It should be noted that the $Q_{\mathrm{O}_{2}}$ should be at least $7-8$ to permit an accurate determination of the low $\mathrm{P} / \mathrm{O}$ ratios found in this organism. With lower values of $Q_{\mathrm{O}_{2}}$ the accuracy of the determination of the phosphate disappearance became limiting. The $Q_{\mathrm{O}_{2}}$ for the oxidation of mannitol, ribitol and galactose was too small $(<5)$ to permit the determination of $\mathrm{P} / \mathrm{O}$ ratios with these substrates. Acetate was not oxidized at all.

TABLE I

$Q_{\mathrm{O}_{2}}(\mu \mathrm{l} / \mathrm{mg}$ PROTEIN/h) FOR THE OXIDATION OF SOME SUBSTRATES BY CRUDE CELL-FREE EXTRACTS OF Gl. liquefaciens (GALACTOSE-GROWN)

Conditions: The Warburg vessels contained : I $\mathrm{ml}$ cell-free extract (Io-I $5 \mathrm{mg}$ protein); $0.7 \mathrm{ml} M / \mathrm{I} 5$ phosphate buffer $\mathrm{pH}$ 6.0. In the side bulb Io $\mu$ moles substrate in $0.2 \mathrm{ml}$. In the centre well o. I ml Iо $\% \mathrm{KOH}$.

\begin{tabular}{lc}
\hline \multicolumn{1}{c}{ Substrate } & Qo2 \\
\hline Glucose & 3 I \\
Ethanol & 49 \\
DPNH & 47 \\
DL-Malate & 22 \\
DL-lactate & 20 \\
Fumarate & 23 \\
Citrate & 19 \\
DL-Isocitrate & 9 \\
$\alpha$-Ketoglutarate & 17 \\
Succinate & 17 \\
G6P & 20 \\
& \\
\hline
\end{tabular}

\section{Oxidative phosphorylation in cell-free extracts}

The results of a typical experiment are given in Table II, to give an indication of the extent of the $\mathrm{O}_{2}$ uptake and phosphate esterification. In Table III the mean $\mathrm{P} / \mathrm{O}$ ratios for a number of substrates are given, together with the probably error of the mean for every substrate. Although the $\mathrm{P} / \mathrm{O}$ ratio found for one substrate with different cell-free extracts varied strongly, it should be noted, that duplicate experiments with one substrate and one cell-free extract always gave practically the sàme $\mathrm{P} / \mathrm{O}$ ratios.

It is obvious that the $\mathrm{P} / \mathrm{O}$ ratios are very low. The $\mathrm{P} / \mathrm{O}$ ratio for $\mathrm{G} 6 \mathrm{P}+\mathrm{TPN}$ is the highest and twice that of TPN. The $\mathrm{P} / \mathrm{O}$ ratio for glucose is very low. We recall here that glycolysis is absent in Gl. liquefaciens and that no phosphate esterification 
TABLE II

$\mathrm{O}_{2}$ CONSUMPTION WITH A NUMBER OF SUBSTRATES AND THE ACCOMPANYING PHOSPHATE ESTERIFICATION BY A CRUDE CELL-FREE EXTRACT OF Gl. liquefaciens (GALACTOSE-GROWN)

Conditions as described under METHODS.

\begin{tabular}{|c|c|c|c|}
\hline Subsirate & $\begin{array}{c}O_{2} \text { consumpition } \\
(\mu \text { moles })\end{array}$ & 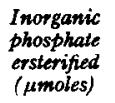 & $P / O$ \\
\hline Glucose & 5.14 & I. 70 & 0.17 \\
\hline G6P + TPN & 6.10 & $4 \cdot 4^{2}$ & 0.36 \\
\hline Citrate + TPN & 5.92 & 2.55 & 0.22 \\
\hline Succinate & 4.61 & 1.28 & o. 4 \\
\hline DL-Lactate & 3.08 & 0.45 & 0.07 \\
\hline Glycerol & 3.43 & 0.02 & o \\
\hline
\end{tabular}

TABLE III

P/O RATIOS WITH A NUMBER OF SUBSTRATES BY CRUDE CELL-FREE EXTRACTS OF GALACTOSE-GROWN CELLS of Gl. liquefaciens

Conditions as described under METHODs.

\begin{tabular}{llcl}
\hline \multicolumn{1}{c}{ Substrate } & $\begin{array}{c}\text { Mean } P / O \text { ratio and } \\
\text { probable error of the mean }\end{array}$ & $\begin{array}{c}\text { Number of } \\
\text { determinations }\end{array}$ & Range \\
\hline Glucose & & & \\
Ethanol & $0.15 \pm 0.01$ & 8 & $0.12-0.19$ \\
DPNH & $0.10 \pm 0.005$ & 7 & $0.07-0.11$ \\
TPNH & $0.09 \pm 0.01$ & 5 & $0.06-0.13$ \\
DL-Lactate & 0.22 & 2 & $0.21-0.22$ \\
Glycerol & $0.16 \pm 0.01$ & 10 & $0.07-0.21$ \\
Succinate & 0 & 3 & 0 \\
Citrate + TPN & $0.23 \pm 0.02$ & 8 & $0.14-0.36$ \\
G6P + TPN & $0.24 \pm 0.01$ & 7 & $0.18-0.32$ \\
$\alpha$-Ketoglutarate + DPN & $0.40 \pm 0.05$ & 7 & $0.27-0.66$ \\
& $0.22 \pm 0.01$ & 5 & $0.16-0.24$ \\
\hline
\end{tabular}

at substrate level can occur. It would be possible that part of the glucose is phosphorylated by the ATP formed and that a part of the phosphate esterification during glucose oxidation is due to $\mathrm{G} 6 \mathrm{P}$ oxidation. This is not probable as $\mathrm{CO}_{2}$ is evolved during $\mathrm{G} 6 \mathrm{P}$ oxidation and with glucose no $\mathrm{CO}_{2}$ evolution was observed. The fraction of glucose oxidized via G6P must be very small. Furthermore the $\mathrm{P} / \mathrm{O}$ ratio with glucose by the particulate fraction (which contains no G6P-dehydrogenase) was only slightly lower than that by the crude extract. The $\mathrm{P} / \mathrm{O}$ ratio found for glucose is consequently due to the direct unphosphorylated oxidation of glucose.

During the direct oxidation of glycerol (to dihydroxyacetone) no phosphate esterification occurs.

With isolated particles oxidative phosphorylation could be detected with glucose (P/O, o.I4), ethanol (P/O, o.I3), TPNH (P/O o.I9) and DPNH (P/O, o.I3).

The low values of the $\mathrm{P} / \mathrm{O}$ ratios are probably due to a low efficiency of oxidative phosphorylation in this organism as will be argued below. To exclude as far as possible the possibility of unfavourable experimental conditions the influence of some variations in the test system or in the growth conditions were studied. 


\section{Infuence of warying experimental conditions on the $P / O$ ratios}

Influence of $p H$ : Some experiments were performed at $\mathrm{pH}$ 7.2. For this purpose a batch of cells was divided into 2 equal parts. From one part a cell-free extract was prepared as usual and the $\mathrm{P} / \mathrm{O}$ ratios were determined in the normal way. From the other part a cell-free extract was prepared of cells suspended in $M / 30$ phosphate buffer at $\mathrm{pH}$ 7.2. For the determination of the $\mathrm{P} / \mathrm{O}$ ratios the acetate buffer was replaced by a same amount of Tris buffer at $\mathrm{pH}$ 7.2. The result of one of these experiments is shown in Table IV. At $\mathrm{pH} 7.2$ the $\mathrm{P} / \mathrm{O}$ for $\mathrm{G} 6 \mathrm{P}$ is lower and that for citrate is higher than that at $\mathrm{pH}$ 6.o. It should be noted, that $\mathrm{O}_{2}$ uptake at $\mathrm{pH} 7.2$ is slower than at $\mathrm{pH} 6.0$ (glucose oxidation in this organism has a $\mathrm{pH}$ optimum of approx. 5.5).

\section{TABLE IV}

INFLUENCE OF $\mathrm{pH}$ ON THE P/O RATIOS WITH SOME SUBSTRATES BY CELL-FREE EXTRACTS OF GALACTOSE-GROWN CELLS OF Gl. liqu afaciens

\begin{tabular}{lcc}
\hline \multicolumn{1}{c}{ Substrate } & $P / O p H 7.2$ & $P / O p H 6.0$ \\
\cline { 2 - 3 } Glucose & 0.12 & 0.12 \\
Citrate + TPN & 0.42 & 0.27 \\
G6P + TPN & 0.23 & 0.32 \\
\hline
\end{tabular}

\section{TABLE V}

INFLUENCE OF THE SPEED AT WHICH THE CELL-FREE EXTRACT HAD BEEN CENTRIFUGED ON THE P/O RATIOS WITH CELI-FREE EXTRACTS OF GALACTOSE-GROWN CELLS OF Gl. liquefaciens

Conditions as described under METHODS.

\begin{tabular}{crcccc}
\hline Expt. & Speed and time of centrifugation & $P / O$ glucose & $P / O$ lactate & $P / O$ succinate \\
\hline & & & & \\
I & I 5 min at $12000 \times g$ & 0.17 & & \\
I & 45 min at $12000 \times g$ & 0.28 & & \\
2 & I 5 min at $12000 \times g$ & 0.16 & 0.17 & 0.20 \\
2 & I 5 min at I $2000 \times g$ & & & \\
& $+30 \mathrm{~min}$ at $19000 \times g$ & 0.28 & 0.18 & 0.27 \\
\hline
\end{tabular}

Infuence of the speed of centrifugation of the cell-free extracts on the $P / O$ ratios with glucose: TISSIÈRES, HovenKAMP AND SLATER ${ }^{12}$ showed for Azotobacter vinelandii that the small particles in the cell extract gave higher $\mathrm{P} / \mathrm{O}$ ratios than the larger particles. We consequently centrifuged a cell-free extract at different speeds for various times and studied oxidative phosphorylation in the supernatants. The results are shown in Table $\mathrm{V}$. With glucose it is obvious that longer centrifugation increased the $\mathrm{P} / \mathrm{O}$ ratios. With lactate and succinate this effect was much smaller or absent. Continued centrifugation above the times mentioned in Table $\mathrm{V}$ gave a decrease of the $\mathrm{P} / \mathrm{O}$ values.

Influence of growth conditions: The reported results have been obtained with extracts from cells grown for $4^{8} \mathrm{~h}$ on a medium with $0.4 \%$ of galactose. Extracts from cells grown on the same medium for $24 \mathrm{~h}$ gave virtually the same results, indicating that the age of the culture is not an important variable.

The composition of the growth medium proved important, however. With extracts from cells grown in a medium with $2 \%$ galactose much lower $\mathrm{P} / \mathrm{O}$ ratios were 
obtained for glucose ( $0.05 \pm 0.01,7$ determinations) and for $\alpha$-ketoglutarate + DPN (0.Io $\pm 0.01,3$ determinations). The $\mathrm{P} / \mathrm{O}$ ratios for $\mathrm{G} 6 \mathrm{P}$ and citrate were not affected by the change in growth medium. In the medium with $2 \%$ galactose growth was poorer and the $\mathrm{pH}$ dropped. Though the oxidative capacities from the resulting cell extracts were not affected some $\mathrm{P} / \mathrm{O}$ ratios were reduced.

When cells were grown in a medium with glucose or gluconate no phosphate esterification could be observed in the cell-free extract with glucose (4 experiments) or with lactate (2 experiments); with ethanol a lower $\mathrm{P} / \mathrm{O}$ ratio was observed $(\mathrm{P} / \mathrm{O}=0.04)$. With DPNH, G6P and citrate the $\mathrm{P} / \mathrm{O}$ ratios were equal to those with extracts from galactose-grown cells.

It seems then that oxidative phosphorylation with glucose as a substrate is very sensitive to growth conditions but that oxidative phosphorylation with other substrates is much less affected. Though the metabolism of glucose is different in glucosegrown and galactose-grown cells, the first oxidative steps (to gluconate and to 2 -ketogluconate seem to be the same and an explanation for the different $\mathrm{P} / \mathrm{O}$ ratio is lacking. The possibility that some product of the glucose oxidation in glucose-grown cells (f.i. 2,5-diketogluconate or the $\gamma \cdot$ pyrones $\left.^{3,13,14}\right)$ inhibits phosphorylation has not been excluded.

Influence of inorganic phosphate and ATP concentration: With higher ATP and inorganic phosphate concentrations a somewhat higher $\mathrm{P} / \mathrm{O}$ ratio was found in some experiments. In most experiments no influence on the $\mathrm{P} / \mathrm{O}$ ratio could be detected, however, by a change in the ATP or inorganic phosphate concentration.

\section{Cytochromes in Gl. liquefaciens.}

The $\mathrm{P} / \mathrm{O}$ ratios with cell-free extracts of $\mathrm{Gl}$. liquefaciens are very low. One of the reasons for this could be that the respiratory chain of this organism contains fewer steps than that in mitochondria. With a spectroscope 2 absorption bands could be

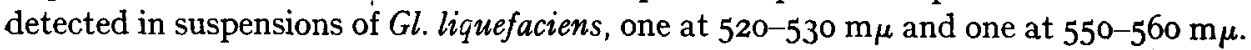

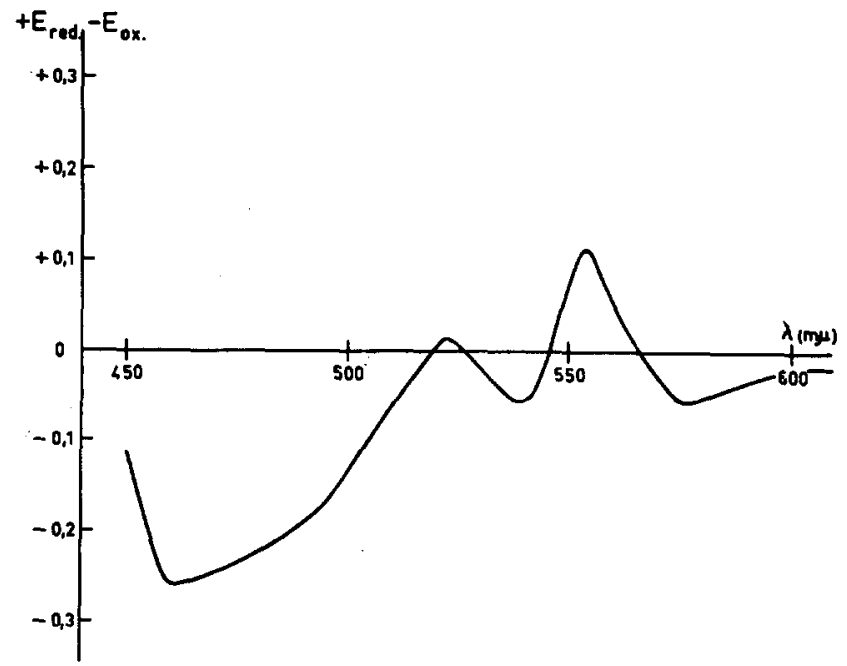

Fig. I. Spectrum of the difference in absorption between reduced and oxidized particles of $G l$. lizuefaciens. The particles were reduced by incubation with $0.007 M$ DL-lactate and oxidized by shaking in air. Protein concentration approx. $30 \mathrm{mg}$ protein/ml. Measured in the Beckman DU spectrophotometer with a slit width of $0.02 \mathrm{~mm}$. 
Below $470 \mathrm{~m} \mu$ complete absorption occurred. No band between 580 and $630 \mathrm{~m} \mu$ could be detected even in very thick suspensions (40 $\mathrm{mg}$ dry wt./ml). The absorption of thick suspensions of whole cells was measured (after treatment with $\mathrm{Na}_{2} \mathrm{~S}_{2} \mathrm{O}_{4}$ ) in the Beckman spectrophotometer against diluted milk as a blank. With this technique absorption maxima were found at $4 \mathrm{I} 8,523$ and $553 \mathrm{~m} \mu$. No maxima were seen between 580 and $630 \mathrm{~m} \mu$ and the $\alpha$ - and $\beta$-band did not show shoulders. With the same technique the presence of cytochrome $a_{3}$, cytochrome $b_{2}$ and cytochrome $c$ could easily be detected in baker's yeast and the presence of cytochrome $a$, cytochrome $b$ and cytochrome $c$ in rat-Jiver mitochondria. In both cases the absorption maxima were found at the wavelengths reported in the literature. The difference spectrum of isolated particles is shown in Fig. $\mathrm{I}$, for the region 450-6ro $\mathrm{m} \mu$. Absorption maxima are found at 554 and $523 \mathrm{~m} \mu$. The difference spectrum between 400 and $460 \mathrm{~m} \mu$ was measured'with more diluted suspensions. The absorption maximum was at $424 \mathrm{~m} \mu$. It is very likely that in Gl. liquefaciens only one cytochrome is present. In Acetobacter suboxydans, which is closely related to Gl. liquefaciens, Smiтн ${ }^{15}$ equally detected only one cytochrome with absorption maxima at 422,525 and $554 \mathrm{~m} \mu$. It is probable that this cytochrome is identical to the one found in Gl. liquefaciens. $p$-Phenylenediamine was only slowly oxidized by cell-free extracts and the rate of the $\mathrm{O}_{2}$ 'uptake was not increased by the addition of mammalian cytochrome $c$. Cytochrome $c$ oxidase is thus absent in this strain.

Influence of DNP on oxidative phosphorylation, oxidation and substrate assimilation

The $\mathrm{P} / \mathrm{O}$ ratios in the presence of DNP for some substrates are shown in Table VI. DNP has only a slight influence on the $\mathrm{P} / \mathrm{O}$ ratios and even with $10^{-3} M \mathrm{DNP}$ no complete uncoupling of oxidation and phosphorylation occurs.

TABLE VI

INFLUENCE OF DNP ON THE P/O RATIOS WITH SOME SUBSTRATES BY CELL-FREE EXTRACTS OF GALACTOSE-GROWN CELLS OF Gl. liquefaciens

Conditions as described under METHODS

\begin{tabular}{|c|c|c|c|}
\hline Substrate & $\begin{array}{l}\text { P/O without } \\
\text { DNP }\end{array}$ & $\begin{array}{c}P / O+ \\
I O^{-4} M+\end{array}$ & $\begin{array}{c}P / O+ \\
r O^{-3} M D N P\end{array}$ \\
\hline \multirow[t]{4}{*}{ Glucose } & 0.17 & & O.I I \\
\hline & 0.16 & & 0.07 \\
\hline & 0.19 & 0.17 & 0.08 \\
\hline & 0.24 & 0.22 & o. I 4 \\
\hline \multirow[t]{2}{*}{$\mathrm{G} 6 \mathrm{P}+\mathrm{TPN}$} & 0.49 & & 0.19 \\
\hline & 0.66 & & 0.56 \\
\hline$\alpha$-ketoglutarate + DPN & 0.16 & & 0.02 \\
\hline
\end{tabular}

To see whether this relative insensitivity to DNP is a characteristic property of the phosphorylating system in Gl. liquefaciens the influence of $\mathrm{DNP}$ on $\mathrm{O}_{2}$ consumption was studied with some substrates. DNP $\left(\mathrm{IO}^{-3}\right.$ and $\left.\mathrm{ro}^{-4} M\right)$ was without effect on the oxidation rate of acetate, lactate and succinate by resting cells. The influence of DNP on glucose oxidation by resting galactose-grown cells is shown in Fig. 2. It is evident that $10^{-4}$ and $10^{-3} M$ DNP do not influence the rate of oxidation but only increase the total $\mathrm{O}_{2}$ uptake. This indicates that the rate of oxidation is independent of the 
supply of phosphate acceptor and that no respiratory control—such as exists in animal mitochondria ${ }^{16}$-is present in whole cells of $G$. liquefaciens.

Fig. 2 also shows that $5 \cdot 10^{-3} M$ DNP prevents the phosphorylated breakdown of glucose completely. Indeed in this case glucose was quantitatively converted to 2 -ketogluconate. The fact that the phosphorylated breakdown of 2 -ketogluconate is prevented by this DNP concentration means, that under these circumstances the complete oxidation of 6-PG yields less ATP than the amount needed for the phosphorylation of gluconate. The ATP yield per mole 6-PG is thus less than $\mathrm{r}$.

With galactose-grown cells the $\mathrm{O}_{2}$ uptake with glucose was $3.4 \mathrm{moles} / \mathrm{mole}$ substrate, but in the presence of $\mathrm{DNP}\left(\mathrm{I} \cdot \mathrm{IO}^{-3} M\right)$ the $\mathrm{O}_{2}$ uptake rose to nearly six, i.e. the value for complete oxidation. This indicates that resting cells without DNP assimilate about $45 \%$ of this substrate. Analogous results were obtained with galactose and fructose.

\section{Molar growth yield}

The $\mathrm{P} / \mathrm{O}$ ratios measured with cell-free extract are very low. It was of course possible that these low values were artifacts and that the energy of oxidation was used much more efficiently in growing cells. The molar growth yield $(=\mathrm{mg}$ dry weight of cells/mmole of carbon source utilized) seems to be a measure of the efficiency of oxidative phosphorylation in growing cells, as it has been shown for some micro-

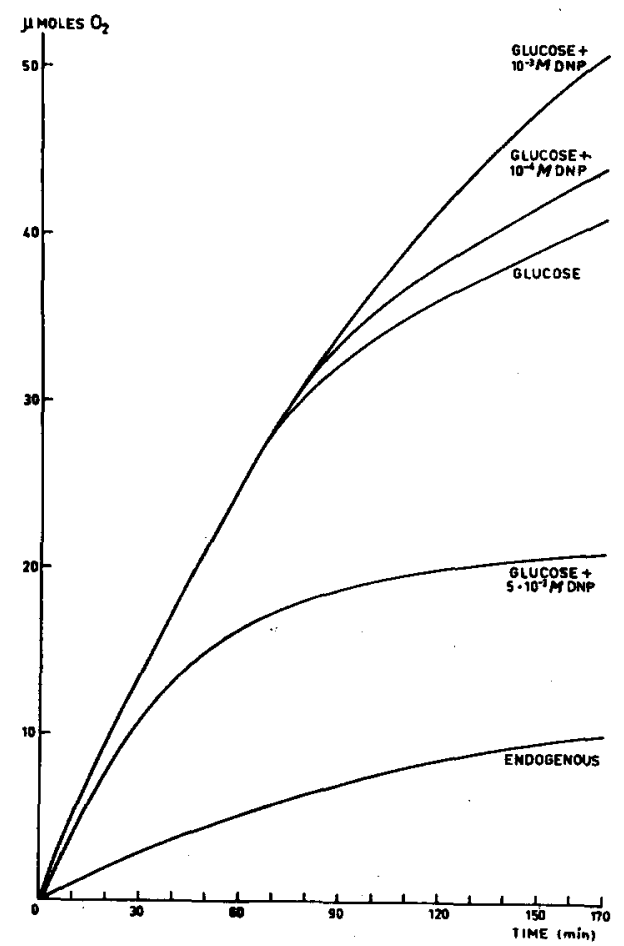

Fig. 2. Oxidation of glucose by resting galactose-grown cells of $\mathrm{Gl}$. liquefaciens in the presence of several DNP concentrations. Content of the Warburg vessels: in the main compartment about $20 \mathrm{mg}$ dry wt. cells in $1.7 \mathrm{ml}$, in the sidebulb to $\mu$ moles glucose in $0.2 \mathrm{ml}$ and $0.1 \mathrm{ml} 10 \% \mathrm{KOH}$ in the centre well. Endogenous respiration was not influenced by the addition of DNP. 


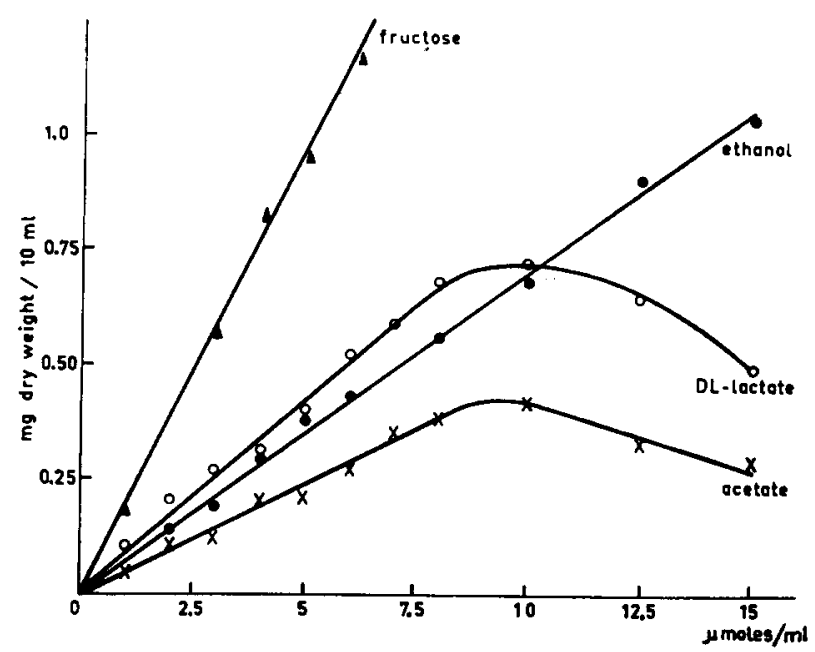

Fig. 3. Growth yield of Gl. liquefaciens for growth in synthetic medium with various amounts of several carbon sources. Composition of the medium and measurement of the amount of growth as described in the text.

\section{TABLE VII}

MOLAR GROWTH YIELD (mg DRY WT. CELLS/mmOle CARBON SOURCE UTILIZED) FOR GROWTH OF Gl. liquefaciens iN SYNTHETIC MEDIUM WITH SEVERAL COMPOUNDS AS SOLE CARBON SOURCE

Conditions: In method a the galactose and fructose content of the medium was determined colorimetrically before and after growth had occurred. The sugar content at the start was approx. $0.5 \%$. Galactose utilization was corrected for galactonate production, which was determined colorimetrically. In method $b$ growth was measured after complete utilization of limiting amounts of carbon source. In both methods the amount of growth was determined by reading the absorbancy at $600 \mathrm{~m} \mu$. The composition of the medium is described under methods. The numbers in brackets give the number of determinations.

\begin{tabular}{lcr}
\hline \multicolumn{1}{c}{ Carbon source } & $\begin{array}{c}\text { Method of } \\
\text { analysis }\end{array}$ & $\begin{array}{c}\text { Molar groweth yield with } \\
\text { probable error of the mean }\end{array}$ \\
\hline Galactose & $a$ & $2 \mathrm{I} .7 \pm \mathrm{I} .0(9)$ \\
Fructose & $a$ & $20.3 \pm \mathrm{I} .4(\mathrm{IO})$ \\
Fructose & $b$ & $2 \mathrm{I} .0 \pm 0.8(\mathrm{I} 3)$ \\
Ethanol & $b$ & $6.8 \pm 0.1(20)$ \\
Acetate & $b$ & $4.8 \pm .3(24)$ \\
DL-Lactate & $b$ & $8.4 \pm 0.7(\mathrm{I} 4)$ \\
Ribitol & $b$ & $\mathrm{I} .3 \pm 0.2(7)$ \\
& & \\
\hline
\end{tabular}

organisms that growth is proportional to the amount of energy (ATP) derived from the carbon source ${ }^{17-19}$.

Growth was measured as described. The amount of carbon source utilized was estimated in two different ways. For galactose and fructose the amount of sugar utilized was calculated from direct estimations of the sugar content of the medium. In other cases cells were grown in synthetic medium with limiting amounts of carbon source. Fig. 3 shows that with ethanol lactate and acetate growth varies linearly with substrate concentration in the range from $0-8 \mu \mathrm{moles} / \mathrm{ml}$. In this range it can be assumed that all the substrate has been utilized as soon as growth is maximal and molar growth yield can then be calculated from the substrate input. This method cannot be 
used for substrates which show a very slow growth rate on low substrate concentrations (f.i. with galactose and mannitol). The molar growth yields obtained with those methods are collected in Table VII.

In complex medium with yeast extract and peptone the growth yield for all these substrates was much higher, which obviously was due to the contribution of the other components of the medium. In complex medium with acetate a rapid increase of the amount of growth was observed with acetate concentrations up to $5 \mu$ moles $/ \mathrm{ml}$. Above this concentration however the amount of growth varied linearly with the acetate concentration and with the same slope as for growth with acetate in synthetic medium (see Fig. 3). This observation enabled us to determine the molar growth yield for ribitol. Ribitol, which is oxidized to D-ribulose, by the cells of Gl. liquefaciens does not support growth neither in synthetic nor in complex media. However in complex medium with $4 \mu$ moles of acetate the amount of growth varied linearly to the ribitol concentration. Molar growth yield could be calculated from this slope.

It is evident from Table VII that all carbon sources are used very inefficiently in this organism ( $20 \mathrm{mg}$ of cell weight from $\mathrm{I} 80 \mathrm{mg}$ fructose etc.) In other bacteria the efficiency of the conversion of the carbon source of the medium into cell carbon is much greater. In Escherichia coli about $50 \%$ of the glucose of the medium is converted into cell carbon ${ }^{20}$ and in Pseudomonas saccharophila $54 \%$ (see ref. 2 I).

\section{DISCUSSION}

The $\mathrm{P} / \mathrm{O}$ ratios found in cell-free extracts of Gl. liquefaciens are very low compared with the $\mathrm{P} / \mathrm{O}$ ratios for mitochondria of animal cells, but similar (though still lower) to those obtained with cell-free extracts of other bacteria as Alcaligenes faecalis ${ }^{\mathbf{2 2 - 2 4}}$, Azotobacter vinelandii ${ }^{12},{ }^{25-30}$, Corynebacterium creatinovorans ${ }^{31}$, Proteus vulgaris ${ }^{32}$ and Nitrobacter agilis ${ }^{33}$. It is known that oxidative phosphorylation is localized on particles, which are formed during the preparation of the cell-free extract by fragmentation of the protoplasmic membrane (see review of $\mathrm{MARR}^{34}$ ). It would be possible that the low $\mathrm{P} / \mathrm{O}$ ratios resulted from damage, during fragmentation. KLUNGSÖYR, KING AND CHELDELIN $^{35}$ who measured $\mathrm{P} / \mathrm{O}$ ratios with whole cells of $A$. suboxydans and CotARobles, Marr AND Nilson ${ }^{36}$ with undamaged protoplasmic membranes ("hulls") of $A$ zotobacter agilis equally found low $\mathrm{P} / \mathrm{O}$ ratios. Thus it seems that the damage caused by the preparation of the cell-free extract is not necessarily the reason for the low $\mathrm{P} / \mathrm{O}$ ratios.

In our case the low $\mathrm{P} / \mathrm{O}$ ratios are not due to damage but truly represent the low efficiency of oxidative phosphorylation in Gl. liquefaciens. This can be argued from the reasonable correspondence between the ATP production found in oxidative phosphorylation and those calculated from substrate assimilation and from molar growth yield.

\section{Substrate assimilation}

During the oxidation of glucose, fructose and galactose by galactose-grown cells $40-45 \%$ of the substrate was assimilated. Assuming that assimilation of hexoses requires 2 ATP as would be the case for assimilation in the form of glycogen ${ }^{37}$, the minimum amount of ATP that must be produced during substrate oxidation can be calculated. When ro moles of hexose are supplied and 5.5 moles are oxidized completely 
(requiring 5.5 moles ATP to feed the substrate into the pentose phosphate cycle) whereas 4.5 moles are assimilated at the cost of 9 moles ATP, the total yield should at least bc I4.5 moles ATP per 5.5 moles of hexose or at least 2.6 moles of ATP per mole of hexose.

Now the $\mathrm{P} / \mathrm{O}$ ratio found for one TPN linked oxidation of G6P was found to be 0.4. If it is assumed that the complete oxidation of a hexose requires I2 such TPN linked oxidations the total yield of ATP/mole hexose would be 4.8 . This figure certainly is a maximum value as the recycling of substrates via the pentose cycle is incomplete and all other $\mathrm{P} / \mathrm{O}$ ratios are smaller.

The maximum value calculated from oxidative phosphorylation (4.8) and the minimum value calculated from substrate assimilation (2.6) are sufficiently near to each other to state that the observed $\mathrm{P} / \mathrm{O}$ ratios with cell extracts are not artifacts but indeed represent the low efficiency of oxidative phosphorylation in this organism.

In most bacteria assimilation is low (see review of CLIFTON ${ }^{38}$ ). Only in Spixillum sp. ${ }^{39}$ and in Mycobacterium phle ${ }^{40}$ assimilation is large. In this aspect it is interesting to note that with cell-free extracts of this last organism high $\mathrm{P} / \mathrm{O}$ ratios have been found ${ }^{28,41-45}$. This suggests a relationship between the $\mathrm{P} / \mathrm{O}$ rati... fon 1 in cell-free extracts and assimilation by resting cells.

\section{Molar growth yield}

Recently BAUCHOP AND ELSDEN ${ }^{19}$ measured the molar growth yield of 3 dif int microorganisms (Saccharomyces cerevisiae, Streptococcus faecalis and Pseudowinas lindneri) in media with limited amounts of several carbon sources. As thece cialyses were performed under anaerobic conditions and after complete utilisation of the carbon source, the total yield of ATP could be calculated, because under these circumstances only phosphorylations at the substrate level occr. They found that for these three organisms the amount of cells formed per mole of ATP gained during the fermentation of the carbon source, was equal at about $10.5 \mathrm{mg}$ dry weight/mmole ATP. This figure was called the $\mathrm{Y}_{\mathrm{ATP}}$. In principle it must be possible to calculate the $\mathrm{Y}_{A+\ldots}$ for our case from $\mathrm{P} / \mathrm{O}$ ratios (Table III) and the molar yield (Table VII). The difficulty is that many substrates undergo only one or a few oxidative steps in the cell-free extracts whereas complete oxidation occurs in growing cells. However in Table VII the difference in molar growth yield for acetate and ethanol $(=2)$ is due to the energy derived from the oxidation of ethanol to acetate. This energy is equal to $2 \times \mathrm{P} / \mathrm{O}$ for ethanol, that is 0.2 moles ATP/mole ethanol. $\mathrm{Y}_{\mathrm{ATP}}$ for Gl.liquefaciens is thus

$$
\frac{Y_{\text {ethanol }}-Y_{\text {acetate }}}{0.2}=\frac{2}{0.2}=10
$$

This figure should still be corrected for an amount of substrate which is converted into cell carbon and which does not contribute to ATP production. This correction is small, however, because the efficiency of this conversion is low. The correction leads to a higher value for $Y_{\mathbf{A T P}}$, but because about the same amount from all substrates is converted to cell carbon, this is having practically no influence on the ATP gain calculated from the corrected molar growth yields and the corrected $Y_{A T P}$. A similar figure(II.2) for $\mathrm{Y}_{\mathrm{ATP}}$ could be obtained from the difference in molar growth yield of acetate and lactate and the $\mathrm{P} / \mathrm{O}$ ratio. If we accept this figure as the $\mathrm{Y}_{\mathbf{A T P}}$ for $G l$. liquefaciens the other molar growth yields of Table VII can be converted to the amounts of ATP gained during the oxidation of each carbon source. These results are given in 
TABLE VIII

ATP GAIN DURING THE OXIDATION OF SEVERAL SUBSTRATES BY GROWING CULTURES OF Gl. liquefaciens CALCULATED FROM THE MOLAR GROWTH YIELDS OF TABLE VII WITH THE AID OF AN $\mathrm{Y}_{\text {ATP }}=10.6$

Mean value of $Y_{A T P}$ calculated from the difference in molar growth yields with ethanol and acetate resp. lactate and acetate.

\begin{tabular}{lcc}
\hline \multicolumn{1}{c}{ Substrate } & $\begin{array}{c}\text { ATP gain per } \\
\text { mole }\end{array}$ & $\begin{array}{c}\text { Total ATP } \\
\text { production per } \\
\text { mole }\end{array}$ \\
\hline Galactose & 2.05 & 3.05 \\
Fructose & 1.95 & 2.95 \\
Ethanol & 0.65 & 1.65 \\
Acetate & 0.45 & 1.45 \\
DL-Lactate & 0.80 & 1.80 \\
Ribitol & 0.12 & 0.12 \\
\hline
\end{tabular}

Table VIII first column. The total amount of ATP produced during oxidation is of course higher as one ATP is generally needed to phosphorylate the substrates before they enter the pentose phosphate or citric acid cycle (Table VIII, second column)

It is evident from Table VIII that the ATP gain from the single oxidative step with ribitol is similar to the $P / O$ ratios found for single oxidative steps with cell-free extracts.

The low molar yields during growth are thus in good accordance with the low $\mathrm{P} / \mathrm{O}$ ratios as the $\mathrm{Y}_{\mathrm{ATP}}$ derived from them are very similar to those found in other organisms.

\section{Low efficiency of oxidative phosphorylation}

The reasonable agreement between the three estimates of "ATP production ( $\mathrm{P} / \mathrm{O}$ ratios, assimilation and molar growth yield) suggest that the energy of oxidation is used very inefficiently in this organism. In agreement with this it was found that growing cultures of this strain gave a large heat production. One reason for the low $\mathrm{P} / \mathrm{O}$ ratios is that the respiratory chain of this organism is having fewer steps than in mitochondria. In extracts we found only I cytochrome (as in Alcaligenes faecalis ${ }^{24}$ ). In Azotobacter vinelandii and in Proteus vulgaris where equally low P/O ratios are found more cytochromes are present ${ }^{\mathbf{4 6 , 4 7}}$ however. In this respect the observation that in whole cells of Gl. liquefaciens no respiratory control is present is of importance. This proves that in whole cells respiration and phosphorylation are not tightly coupled. In this respect these cells behave as "aged" mitochondria.

From the results of Table VIII it is evident that in this organism ATP production per mole hexose oxidized is only slightly higher than that in the anaerobic microorganisms decomposing hexoses by the glycolytic pathway. Gl. liquefaciens has the advantage however that it can obtain energy from the oxidation of acetate and lactate, which the anaerobes cannot.

\section{ACKNOWLEDGEMENTS}

The author is very grateful to Professor Dr. K. C. WINkL ER and to Dr. P. G. DE HAAN for stimulating discussions and for their constant interest. The technical assistance of Miss H. S. FELIX and Miss A. K. Mor is gratefully acknowledged. 


\section{REFERENCES}

1 A. H. Stouthamer, Antonie van Leewwenhoek J. Microbiol. Serol., 25 (1959) 24 I.

2 A. H. Stouthamer, Thesis, University of Utrecht, 1960.

3 A. H. Stouthamer, Biochim. Biophys. Acta, $4^{8}$ (I96I) 484 .

4 J. Deley and M. Doudoroff, J. Biol. Chem., 227 (1957) 745.

5 J. Deley and A. H. Stouthamer, Biochim. Biophys. Acta, 34 (1959) I 7 I.

6 C. H. Fiske and J. Subbarow, J. Biol. Chem., 66 (Ig25) 375.

7 Z. Dische, L. B. Shertles and M. Osnos, Arch. Biochem. Biophys., 22 (1949) 169.

8 T. E. King and V. H. Cheldelin, J. Biol. Chem., 224 (I957) 579.

9 W. D. Trevelyan and J. S. Harrison, Biochem. J., 5o (I952) 298.

${ }_{10} \mathrm{~J}$. H. RoE, J. Biol. Chem., IO7 (1934) I 5.

1 S. Hestrin, J. Biol. Chem., I 80 (1949) 249.

12 A. Tissiekres, H. G. Hovenkamp and E. C. Slater, Biochim. Biophys. Acta, 25 (1957) 336.

13 K. Aida, T. Kojima and T. Asai, J. Gen. Appl. Microbiol., I (1955) I8.

14 K. Aida, M. Fujil and T. Asai, Bull. Agr. Chem. Soc. Japan, 2 I (I957) 30.

15 L. Smith, Bactoriol. Rev. I8 (1954) Io6.

16 H. A. LaRdy and H. WellmanN, J. Biol. Cham., 195 (I952) 2 I 5

$17 \mathrm{~J}$. Monod, Recherches sur la Croissance des Cultures Bactériennes, Herman et Cie, Paris, I942.

18 R. D. DeMoss, R. C. Bard and I. C. Gunsalus, J. Bacteriol., 62 (I95I) 499.

19 T. BAUChOP AND S. R. Elsden, J. Gen. Microbiol., 23 (1960) 457.

20 C. E. Clifton and W. A. Logan, J. Bacteriol., 37 (I939) 523.

21 R. Whelton and M. Doudoroff, $J$. Bacteriol., 49 (1945) 177.

22 G. B. Pinchot, J. Biol. Chem., 205 (I953) 65.

23 G. B. Pinchot, J. Biol. Chem., 229 (I957) I.

24 G. B. Pinchot, J. Biol. Chem., 229 (I957) I I, 25.

25 L. A. Hyndman, R. H. Burris and P. W. Wilson, J. Bacteriol., 65 (1953) 522.

26 A. Tissieres and E. C. Slater, Nature, i 76 (I955) 736.

27 I. Rose and S. OchoA, J. Biol. Chem., 220 (1956) 307.

28 P. E. Hartman, A. F. Brodie and C. T. Gray, J. Bacteriol., 74 (1957) 319.

29 H. G. Hoven Kamp, Biochim. Biophys. Acta, 34 (I959) 485 .

${ }^{30} \mathrm{H}$. G. Hovenkamp, Thesis, University of Amsterdam, 1959.

31 A. F. Brodie and C. T. Gray, J. Biol. Chem., 219 (1956) 853.

32 P. M. Nossal, D. B. Keech and D. J. Morton, Biochim. Biophys. Acta, 22 (1956) 853.

33 E. Malavolta, E. C. Delwiche and W. D. Burge, Biochem. Biophys. Research Communs., 2 (I960) 445 .

${ }^{84}$ A. G. MARR, Ann. Rev. Microbiol., I4 (1960) $24 \mathrm{I}$.

35 L. Klungsöyr, T. E. King and V. H. Cheldelin, J. Biol. Chem., 227 (I957) I35.

2 E. H. Cota-Robles, A. G. Marr and E. H. Nilson, J. Bacteriol., 75 (I958) 243.

37 L. F. Leloir and C. E. Cardini, J. Am. Chem. Soc., 79 (I957) $634^{\circ}$.

*. E. Clifton, Advances in Enzymology, Vol. 6, Interscience Publishers Inc., New York, 1946, p. 269 .

$30 \mathrm{G}$. Giesberger, Thesis, University of Utrecht, 1936.

40 N. L. Edson and G. J. E. Hunter. Biochem. J., 4 I (1947) 139.

41 A. F. Brodie and C. T. Gray, Biochim. Biophys. Acta, i9 (1956) 384.

42 A. F. Brodie, M. M. Weber and C. T. Gray, Biochim. Biophys. Acta, 25 (1957) 448.

43 A. F. Brodie ANd C. T. Gray, Science, 125 (I957) 534.

44 A. F. Brodie, J. Biol. Chem., 234 (1959) 398.

45 A. F. Brodie and J. Ballantine, J. Biol. Chem., 235 (1960) 226, 232.

4 A. Tissieres, Biochem. $J ., 64$ (I956) 582 .

6 H. S. Moyed and D. J. O'Kane, J. Biol. Chem., 218 (1956) 83 I. 